Journal of Balkumari College

ISSN 2467-9321 (Print), ISSN 2738 -957X (Online) Website: http://balkumaricollege.edu.np/journal

Volume : 10 Issue: 1 June 2021, Page No. 1-6

\title{
Attitude Survey on Current Governance System at Tarakeshwar and Tokhain Kathmandu
}

\author{
Dr. Hari Prasad Adhikari \\ Assistant Team, Faculty of Management, TU, Nepal \\ h1p1adhikari@gmail.com
}

\begin{abstract}
This study aims to examinecomponents of local government's development for improving local governance in Nepal. Descriptive and analytical research design was used in this study. The data collected through a questionnaire from 150 respondents were used for analysis. The component of local government for improving local governance in Nepal was found satisfactory, but its implementation was found poor.The findings from this study provide information about Federalismpolicy in Nepal. It could be helpful to provide some particular guidelines to the policymakers for improving local governance. It suggests that appropriate policy must be adopted, and proper communication and information system should be developed.
\end{abstract}

Keywords: Legal framework for local government; financial resources for local governments; Human resources and adequate institutional strengthening to comply with municipal competencies; Transparency and accountability and Institutional arrangements in support of the federalism from the federal government

\subsection{Introduction}

The need for public policy is for the sustained provision of services to citizens efficiently, effectively, and in a responsive manner. Thus, local governance is a public policy issue (Ligal, P., Shrestha, D., Chapagain, Y., Bista, K., \&Maharjan, K., 2005). Local governance in Nepal particularly means democratic participation of the stakeholders in local development. In this process, rural development creates a productive environment for market-led and environment-friendly development that enrichesthe quality of life of the people. The Constitution of Nepal 2015 promulgated by the elected constituent assembly established the local level as full-functional local government units. Article 56 of the Constitution statesthe structure of the state and designates three tiers of governance - federal, provincial and local level. Currently, Nepal is divided into 77 districts, 7 Provinces, and 753 local government units for sharing power among the governments. The role of local government is crucial for federal systems of government where local government is a key interface between civil society and the state; then, local government has to be integrated into the complex structure of a federal system. The major activity of federal, provincial, and local governmentsisto coordinate with each other, yet they are independent of one another. Local leaders rule these local governments and the Mayor is the supreme of each local governmentelected every 5 (Five) years by thelocal public. Effective local governments provide overall quality of life for the people who reside in their communities (Adhikari, 2016).

Federal and provincial laws exist to provide protection for the citizens. While not all duties and responsibilities are defined at the local, provincial and federal levels, the public holds certain expectations for those they elect. People expect that their elected officials will abide by laws and regulations. Beyond that, they expect that their officials will use their resources efficiently and effectively and in ways that provide the most value. Along those lines, people expect that the rates they get charged for services the government provides will be justified and reasonable. People expect their elected officials to be accountable for their actions and decisions. Accountability means that local peoples are entitled to the transparency of information, except forthe information that is confidential.

\subsection{Problem and Research Question}

Development challenges for the twenty-first century revolve around the issues of successful governance. To make development efforts people-centered, effective local governance should be ensured. The core issue of local governance is to ensure social justice and make development inclusive. It encourages access and participation of the marginalized people in local development affairs. Governance is participatory, people-oriented, and involves government bodies, private sector agencies, social groups, communities, and the civil society at large in the pro- 
cess. Federalism assumes that local governance encourages local leadership and empowers the grassroots level to enhance local capacity.

The present Constitution of Nepal, issued on September 20, 2015, has divided the country into 7 provinces with 3 levels of government, central, province, and local government. Article 50(1) of the present Constitution states: the political objective of the state shall be to establish a public welfare system of governance, by establishing a just system in all aspects of national life through the rule of law, values, and norms of fundamental rights and human rights, gender equality, proportional inclusion, participation and social justice, while at the same time protecting the life, property, equality and liberties of the people, in keeping with the vitality of freedom, sovereignty, territorial integrity and independence of Nepal, and to consolidate a federal democratic republican system of governance in order to ensure an atmosphere conducive to the enjoyment of the fruits of democracy, while at the same time maintaining the relations between the federal units on the basis of cooperative federalism and incorporating the principle of proportional participation in the system of governance on the basis of local autonomy and decentralization.Local government can be achieved with proper institutional arrangements; constitutional and legislative frameworks are vital and should be self-explanatory in many cases, a number of federal levels, provincial level, and local level institutions are required to support local governance, particularly, resource mobilization policies and practices are to be placed in different levels of government. In this context, the researcher has attempted to answer the research question: How far are local development components executed for improving local governance?To answer sucha question, it is a challenging context in Nepal.

\subsection{Objective of the Study}

This study aims to map the Attitude of concerned stakeholders regarding the Current Governance System at Tarakeshwar and Tokhain Kathmandu.The specific objective of the study is to examine the components of local development executed for improving local governance in Nepal.

\subsection{Literature Review}

Review of literature captures a number of areas of local governance. The primary intention of this literature review is to provide intensive and extensive knowledge regarding the components of local development.

\subsubsection{LocalGovernance}

UNDP (2004) defines Local governance as "local governance comprises a set of institutions, mechanisms and processes through which citizens and their groups can articulate their interests and needs, mediate their differences, and exercise their rights and obligations at the local level. The building blocks of good local governance are many: citizen participation, partnerships among key actors at the local level, capacity of local actors across all sectors, multiple flows of information, institutions of accountability, and a pro poor orientation "(UNDP, 2014).

There is a large degree of synergy and coherence between supporting national governance processes and local governance, as many aspects are the same. Therefore, it is necessary to work with governance principles at local levels to strengthen local governance processes.

Strong institutions at the central and local government level are needed for effective local governance, which would bring together all the stakeholders, to work in partnership for local governance; both the local and central government institutions must be strengthened. There is a need for institutional buildings in all sectors. ( Kauzya, n.d).An effective local governance mechanism plays a critical role in economic development and social justice (Haque,T.M. 2009).

According to (DFDP, 2006), "Local governance is in the actual actors participating in the process and the mode of interaction between governments, the private sector and civil society. Local governance pertains more to supporting the creation of an enabling environment where multi stakeholder processes including the public and private sector, as well as civil society".

Based on the experiences and lessons learned in this field by eminent experts and practitioners, the key policy messages and recommendations for local governance-decentralization or decentralized governance, can be summarized as follows (Rojas R., 2014): There is a need for sustained commitment, coordination and strengthened capacities of all stakeholders at various levels for poverty reduction through local government; there must be an enabling environment at the national/federal level to ensure the autonomy of power/authority to the local level 
for community empowerment; there is need to give importance to administrative, fiscal and political autonomy, to contribute to poverty reduction; participatory monitoring and evaluation at all levels should be emphasized effective local governance; initiatives of local government should be context-specific for motivating local people for their own development.

\subsubsection{Component of local government's development}

From the various literature, different issues were identified concerning the local government's development and federalism. These issueswere considered the components of federal, provincial, and local governance strategies conducive to successful federalism and local governance. They were: legal framework for local government; financial resources for local governments; human resources and adequate institutional strengthening to comply with LG competencies; transparency and accountability, and institutional arrangements supporting the LG from the federal government.

\subsubsection{Legal Framework for local government}

The Local Governmentoperation Act, 2017, Inter-governmental fiscal transfer Act, 2017, National natural resource and finance Act, 2017, and other related Act.,Regulations are the major guideline in the local development process in Nepal. Such acts and regulations built and improved the existing legal framework for local government. It legitimized the concept of self-governance and enumerated the objectives, principles, duties, and responsibilities for local governance in the country. It also provided financial support to the local level government through revenue assignment, central government grants, and domestic borrowing, operational autonomy, accountability, and transparency mechanisms, ensuring representation of women and disadvantaged groups. It helped develop federalism and local development implementation activities.

\subsubsection{Financial Resources for Local Governments}

In the context of federalism, the availability of financial resources for local governance is an essential factor. Fis$\mathrm{cal}$ resource for local governance indicates transferring adequate budget and trained manpower to carry out tasks such as the assignment of local revenue taxes or agriculture extension activities.

\subsubsection{Competent Human Resources Management}

Planning, implementing, and managing devolved functions cannot be carried out without competent human resources and adequate institutional strengthening. Compliance with required accounting, financial reporting, and auditing standards, ensuring accountability and transparency, are closely related to human resources' skills and competencies and adequate institutional strengthening.

\subsubsection{Transparency and Accountability}

Transparency in a social context more generally implies openness. It is used as a means of holding public officials accountable and fighting corruption. It also refers to the availability and accessibility of information to those affected by public decisions and their enforcement (Adhikari, 2013). On the other hand, accountability denotes the effectiveness with which the governed can exercise influence over their governors (Rijal, 2011). In ethics and governance, accountability is answerability, blameworthiness, and liability.

\subsubsection{Institutional Arrangements in Support of local government}

The institutional arrangements for the management of the federalism and local government include the leadership role within government for the process, the implication of core stakeholders, and the interrelation of the management structures for the local government with the arrangement of broader public management. The government system and local governance are inextricably linked to each other. The degree of achieving the objectives of local government largely depends upon the nature of the structure of the federal-local government relationship. Conceptually both federal and local governments have a common goal of promoting public welfare through the provision of adequate delivery of services and goods (Adhikari, 2020).

Considering theliterature mentioned above, successful federalism can create a big difference by creating more competent, fair, sustainable, and cost-effective local services because of greater accountability, responsiveness, and participation. It can improve the quality of life of the poorer and marginalized sectors of the population through community participation in decision making, planning, and implementation and monitoring, supported 
by appropriate institutions and resources, which would eventually lead to poverty alleviation.

\subsection{Methodology}

The present study is based on the survey design. An interview schedule was administered in 2020. The population for this study was taken fromTarakeshwar and Tokhain Kathmandu district for analyzing "Component of local government's development for Improving Local Governance in Tarakeshwar and Tokha". The survey was conducted during a comparatively milder period of the Coronavirus pandemic.Convenient sampling was used for selecting the location. The population comprised of local people, local leaders, government officials, academics, NGO/CBO officials, and employees of municipalities from Tarkeshwar and Tokha. A sample size of 100 was taken from an infinite/unknown population. Purposive quota sampling technique was used. The quota was determined based on the size of the population and researcher convenience. The variation of components of local governmentwas measured in terms of the variation of group of stakeholders. Tarakeshwar covers the former Village Development Committees Dharmasthali, Futung, Goldhunga, Jiturphedi, Kavresthali, Manmaiju, and Sangla. Similarly, Tokha covers the former Village Development CommitteesDhapasi, JhorMahankal, Gongabu, TokhaChandeshwari, and TokhaSaraswati.A five-point Likert scale was used to analyze the data, the weighted mean score was computed, and the local government's execution level was measured.

\subsection{Survey Findings}

This section narrates the survey findings andan overview of research on the execution of the components of local government. The local government's development components are considered a national federalism strategy to be conducive for successful federalism and the coordinated and harmonized federalism and local government policy to support federalism and local governance. Legal framework for local government, financial resources for local governments, human resources and adequate institutional strengthening to comply with LG competencies, transparency and accountability, and institutional arrangements supporting federalism and local governance are considered the local government's development components. Respondents view regarding the execution of the components of local government is shown in table 01

Table: 01 Execution of the component of local government's development

\begin{tabular}{|c|c|c|c|c|c|c|c|}
\hline \multirow{2}{*}{$\begin{array}{c}\text { Components of local } \\
\text { government's development }\end{array}$} & \multicolumn{5}{|c|}{ Extent of Execution level } & \multirow{2}{*}{ Rank } & \multirow{2}{*}{$\begin{array}{l}\text { Weighted Mean Score } \\
\quad(\text { Range }=1 \text { to } 5)\end{array}$} \\
\hline & VH & $\mathrm{H}$ & $\mathrm{N}$ & $\mathrm{L}$ & VL & & \\
\hline $\begin{array}{l}\text { a. Legal framework for local } \\
\text { government }\end{array}$ & 20 & 60 & 10 & 8 & 2 & 1 & 3.88 \\
\hline $\begin{array}{l}\text { b. Institutional arrangements in } \\
\text { support of local government }\end{array}$ & 5 & 20 & 28 & 32 & 15 & 5 & 2.68 \\
\hline $\begin{array}{ll}\text { c. Transparency and } \\
\text { accountability; }\end{array}$ & 10 & 25 & 17 & 35 & 13 & 4 & 2.84 \\
\hline $\begin{array}{l}\text { d. Financial resources for local } \\
\text { government; }\end{array}$ & 6 & 30 & 55 & 5 & 4 & 3 & 3.29 \\
\hline $\begin{array}{l}\text { e. Human resources and adequate } \\
\text { institutional strengthening to } \\
\text { comply with local competencies; }\end{array}$ & 12 & 35 & 39 & 11 & 3 & 2 & 3.42 \\
\hline
\end{tabular}

Number of Respondents $=100$

The views expressed by different respondents are listed in table 01 on the execution of the components of local government. As stated above, the extent of execution level ofthe Legal framework for local government, Human resources and adequate institutional strengthening to comply with local competencies, and Financial resources for local governmentwere found strong because the weighted mean score value of them are3.88 and 3.42 and 3.29 which are greater than the median value 3.0. As per the opinion of the majority of the respondents, the causes forthe strong legal framework for local developmentare the provision of autonomy, accountability, transparency, representation of women, marginalized group's execution of local development implementation plan in the Lo- 
cal Government operation Act, 2017and other relevant Act and regulations. Similarly, the cause for the strong execution of the human resources and adequate institutional strengthening to comply with local competencies are proper planning, compliance with required standards for accounting, financial reporting and auditing, ensuring accountability and transparency are closely related with the skills and competencies of human resources and adequate institutional strengthening. Likewise, the cause for the strong execution of the financial resources for local government is transferring adequate budget and trained manpower to carry out tasks as the assignment of local revenue taxes or agriculture extension activities.

On the other hand,Institutional arrangements in support of the local government, and Transparency and accountabilityare weak because their weighted mean score values are 2.68 and 2.84, which are smaller than the median value of 3.0. The cause for the weak execution level of institutional arrangements is due to the weak leadership role. As per most respondents, the causes forthe weak execution level of transparency and accountability area lack of openness. Public officials are not able to be accountable and fighting corruption. Similarly, lack of availability and accessibility of information to those affected by public decisions and their enforcement, mounting irregularities, corruption, ineffective communication and information are other reasons for the low execution level of transparency and accountability.

\subsection{Conclusion}

A survey was conducted about the current local governance system by considering the population of Tokha and Tarkeshwar and taking a sample from the same two places. The survey results indicated that the local government operation Act, 2017, Inter-governmental fiscal transfer Act, 2017, National natural resource and finance Act, 2017, and other related Act, Regulations are the major guideline in the local development process in Nepal. Article 50(1) of the Constitution of Nepal-2015 has made some provisions regarding local development.

From the study, a conclusion can be drawn that the execution level of the legal framework for local development; and institutional arrangements in support of local development process from the central level was found strong, whereas the execution level of transparency and accountability; financial resources for local governments; and human resources and adequate institutional strengthening to comply with local competencies were found weak.

The implications of the findings regarding federalism and local governance seem inseparable in practice as they co-exist together. The essence of federalism and local governance is the interplay between the local and federal level actors.

The repartition of the roles of different actors is an essential consideration in the context of local governance as there are multiple sectors and levels involved in the functioning of local governments' initiatives for service delivery.

\subsection{Limitations and Direction for Further Research}

This study focuses only on the component of local government to improve local governance. The primary data has been taken from only two areas. The study areas have been chosen based onthe researcher's convenience. The perception analysis done on the two areas might not represent the entire national state. Despite the efforts to make the respondents aware of federalism, local government, and local governance, due to the difference in the level of the respondents, there might have been some biasness in the response that has not been considered in this study. This study was conducted during a mildly affected period dueto the Coronavirus pandemic, and during the process of executing federalism, so most people believed that federalism could solve all the problems. The perception of the respondents might have been influenced by sucha period. The study revolves around the fact that local governance is affected by federalism. Thus, this study focuses only on the level of execution and success of the local government, as it automatically results in an effective local governance. This study has not analyzed the cause and effect relationship of local government and effective local governance. To identify the actual relationship betweenlocal government and local governance, the cause and effect relationship study would be suggested. 


\section{REFERENCES}

Adhikari, H. P. (2020). Effectiveness of Local Government in Nepal and result oriented prosperity, Civil Service Journal, 41(1)48-55, Published by Public Service Commission, Nepal.

Adhikari, H. P. (2016). Decentralization for Effective Local Governance in Nepal (Ph.D.).Tribhuvan University, Nepal.

Adhikari, H. P. (2013). Performance-based grant system in local governance in Nepal: A study of Banke and Dolpa district development committees (M.Phil.). Tribhuvan University, Nepal.

Constitution of Nepal. (2015).

Decentralized Financing and Development Programme (DFDP). (2006). Annual Progress Report of Decentralized Financing and Development Programme. A report submitted to UNCDF and MoLD, Nepal. Kathmandu: DFDP.

Haque, T.M. (2009). Challenges of people's participation at local governance: A case study on the standing committees of union parishad in Bangladesh. Nepalese Journal Of Public Policy And Governance, XXIV(1), 67-85.

Inter-governmental fiscal transfer Act, 2017, Nepal

Kauzya, J. (n.d.). Local governance capacity building for full range participation: Concepts, frameworks, and experiences in African countries. United Nations Public Administration Network. Retrieved from http:// unpan1.un.org/intradoc/groups/public/documents/un/unpan005783.pdf

Ligal, P., Shrestha, D., Chapagain, Y., Bista, K., \&Maharjan, K. (2005). Fiscal decentralization in Nepal status and the way forward. Decentralization Advisory Support Unit/ DANIDA. Retrieved from http://prad-nepal. com/wp-content/uploads/2012/11/FISCAL-DECENTRALISATION-Eng2.pdf

Local Government operation Act, 2017, Nepal

National natural resource and finance Act, 2017, Nepal

Rijal, Y. R. (2011). Government institutions and local governance. Kathmandu:Bhrikuti Academic Publication.

Rojas, R. (2014). On decentralization and privatization Decentralisation and Local Governance: benefits and limits. The Robinson Rojas Archive. Retrieved 5 September 2014, from http://www.rrojasdatabank.info/ decentlimits.htm

UNDP. (2004). Decentralized Governance for Development: A Combined Practice Note on Decentralisation, Local Governance and Urban/Rural Development. (UNDP Practice Note) Retrieved from http://www.undp. org/content/dam/aplaws/publication/en/publications/democratic-governance/dg-publications-for-website/ decentralised-governance-for-development-a-combined-practice-note-on-decentralisation-local-governance-and-urban-rural-development/DLGUD_PN_English.pdf

UNDP. (2014). Users' Guide to Measuring Local Governance. Retrieved from http:/gaportal.org/sites/default/ files/LG\%20Guide.pdf 